\title{
Funcțiile stilului în retorica creștină a Sf. Augustin
}

\author{
Ioan Milică ${ }^{\oplus *}$ \\ Facultatea de Litere, Universitatea „Alexandru Ioan Cuza”, Bd. Carol I 11, 700506 Iași, România
}

\section{Despre articol \\ Istoric:}

Primit 16 decembrie 2014

Acceptat 4 ianuarie 2015

Publicat 13 ianuarie 2015

Cuvinte-cheie:

elocuție

predică

retorică creștină

\begin{abstract}
Rezumat
Răspîndirea creștinismului a determinat schimbări culturale majore în Europa și în întreaga lume. Fără a insista asupra relațiilor dintre noua religie și cultura clasică, este suficient să arătăm că, în planul artei de a vorbi convingător, perspectiva asumată de părinții Bisericii creștine a favorizat, pe de o parte, supraviețuirea unora dintre lucrările de elocință ale Antichității, și, pe de altă parte, a condus la instaurarea unei retorici religioase care s-a desprins treptat de sub tutela vechilor modele. Lucrarea de față are ca obiectiv de bază prezentarea sintetică și sistematică a concepției Sf. Augustin asupra importanței și funcțiilor elocuției, pentru a reliefa inovațiile pe care acest gînditor le aduce canonului retoric clasic.
\end{abstract}

\section{Introducere}

Spiritualitatea creștină impune un gen retoric nou ${ }^{1}$, arspredicandi (Copeland \&Ziolkowski, 2006, p. 494), și, pe fondul tradiției retorice participative pe care a moștenit-o și a întreținut-o, fixează opoziția între rhetorica humana și rhetorica divina (Knape, 2008, p. 62). Mai mult decît atît, cele două practici discursive, laică și sacră, sînt, în viziunea Sf. Ambrozie (Murphy, 2001, p. 52), manifestări ale unor categorii distincte de înțelepciune, umană (sapientia saculi) și divină (sapientia spiritualis). Tensiunea dintre cele două paradigme culturale, precreștină și creștină, îi preocupă pe toți marii gînditori și trăitori creștini din primele secole ale mileniului I și se extinde dincolo de sfera artei de a comunica bine, frumos și convingător. Într-o epistolă către Iulia Eustochium² ${ }^{2}$, Sf. Ieronim, unul din cei patru părinți ai Bisericii Apusene și mare traducător al Bibliei, pune foarte plastic în evidență falia crescîndă dintre valorile culturale ale Antichităţii și universul spiritual al creștinismului: „Ce are în comun lumina cu întunericul? Ce armonie poate fi între Hristos și Belial? Ce au a face Horațiu cu Psaltirea, Vergiliu cu Evangheliile și Cicero cu Apostolul (Pavel)? ... să nu bem din pocalul lui Hristos și din cupa diavolului în acelaşi timp." (Murphy, 2001, p. 53).

În ciuda distanțării de modelele antice, nu este lipsit de importanță să constatăm că tradiția iudaică și cea greco-latină au contribuit în chip diferit, dar consistent la închegarea, dezvoltarea și rafinarea unor tipare discursive întemeiate pe rugăciune și pe citirea și comentarea Scripturii. Actul de a transmite învățătura sacră prin apostolat este, în raport cu tradiția retorică greco-latină, o inovație: „Hristos”, observă James Murphy (2001, p. 273), „a introdus un element retoric inexistent pînă atunci în istoria umanității, anume dispoziția ca discipolii să-i răspîndească ideile prin viu grai”. Pe fondul distincției între 'a predica' și 'a învăța', distincție respectată și practicată în vremea lui Iisus, modelele retorice creștine (catehetic și omiletic, mai ales) fondate pe autoritatea Bibliei și întărite de autoritatea cuvîntului lui Hristos au presupus de la început, și predicile hristice o dovedesc fără tăgadă, o împletire între hermeneutică și exortație (Murphy, 2001, p. 278), iar o astfel de legătură între ceea ce se adresează minții și ceea ce se adresează inimii a determinat crearea, respectarea și conservarea unor cadre discursive potente.

Pentru predicator, Scriptura, considerată ca text revelat, devine reper unic de adevăr, autoritate și ideal de elocvență. Susţinut de litera și spiritului textului sacru și hrănit cu învățăturile fondatorilor Bisericii,

*Adresă de corespondență: ioanister@gmail.com.

${ }^{1}$ În Evul Mediu se cristalizează (cf. Murphy, 2001) un canon retoric cu trei genuri: arta de a predica (ars predicandi), retorica versificației (ars poetrie) și genul epistolar (ars dictaminis).

${ }^{2}$ Fiică a unor aristocrați romani creștini, Iulia Eustochium (368-419 d.Hr.) s-a dedicat ascezei și l-a ajutat pe Sf. Ieronim în activitatea sa misionară și cărturărească. În Biserica Catolică, este celebrată ca sfintă în ziua de 28 septembrie. 
oratorul creștin va căuta ca în cuvintările sale să exprime doar adevărul de credință, iar funcția persuasivă a discursului este dublată de o funcție performativă. Cuvîntul este menit a se edifica în și prin faptă, după cum fapta trebuie să aibă proprietatea de a fi o punere în practică a cuvîntului, iar această observație ne permite să afirmăm că retorica religioasă creștină este o retorică întemeiată pe conlucrarea între ceea ce se spune (gr. legomena) și ceea ce se face (gr. drömena) (Dowden, 2007, p. 320-333).

Intenția de comunicare care animă și hrănește energiile predicii este aceea de a interacționa cu membrii comunității creștine, spre a le induce o mentalitate și spre a le dezvolta orizonturi noi de înțelegere și de comportament. Această schimbare de perspectivă asupra actului de a cuvînta, dinspre EU spre TU/VOI, va deveni, mai apoi, prin misiunile apostolice și prin activitatea cultural-religioasă a marilor spirite ale creștinătății, trăsătura definitorie a procesului de comunicare prin care s-a asigurat răspîndirea Scripturii. Altfel spus, spre deosebire de oratorul antic (păgîn), artizan pregătit și priceput în a explora potențialul persuasiv și expresiv al faptelor de limbaj, indiferent de valoarea de adevăr a acestora, oratorul medieval (creștin) angajează în discurs calitățile sale de interpret autorizat al textului biblic și de apărător al credinței (Clarke, 1996, p. 153). Pătruns de adevărul revelat de textul sacru, predicatorul nu va mai pune atît de mult preț pe ornarea verbală a discursului cît pe înțelegerea și comentarea eficientă a învățăturilor de credință, iar ceea ce profilează identitatea persuasivă și expresivă a predicii este triada Scriptură - predicator - credincioși (Kneidel, 2006, p. 362).

În opinia multor cercetători, primul tratat medieval de retorică creștină este lucrarea Sf. Augustin, $D e$ doctrina christiana, elaborată în două etape, despărțite de un interval de trei decenii (396-426). Volumul „pune în prim plan problema elocinței creștine-legitimitatea, funcțiile și principiile ei-și prezintă, în mod convingător, cu exemple și argumente, valențele literare și totodată pedagogice ale textului sacru” (Wald, în Augustin, 2002, p. 9). Alcătuită din patru părți, numite cărți, lucrarea are la bază atît experiența de profesor de retorică a autorului cît şi bogata sa activitate de predicator. În privința reperului retoric valorificat, se știe că Sf. Augustin s-a raportat la lucrările lui Cicero. De altfel, pentru întemeietorii retoricii creștine de pînă în secolul al XIII-lea, perioadă în care învățații din Occident descoperă și traduc lucrările lui Aristotel, retorica ciceroniană este modelul par excellence (Murphy, 2001, p. 106-107). Acest model clasic este prelucrat și acomodat unei sarcini de mare complexitate, relevarea doctrinei creștine, prin reliefarea modelelor de elocință din textul sacru și din apologetica fondatoare. Ampla operație de convertire a culturii clasice ${ }^{3}$ a presupus nu numai cercetarea critică a principiilor, regulilor și tehnicilor de uz curent în oratoria clasică, ci și instituirea de precepte noi și adecvate predicării cuvintului lui Dumnezeu.

În epoca în care Sf. Augustin a definitivat De doctrina christiana, „se simţea necesitatea unei noi retorici, existînd pericolul ca elocința sacră să fie impregnată de atmosfera sofistică și de un exces de erudiție" (Wald, în Augustin, 2002, p. 17), așa că ilustrul și luminatul învăţat va fi simţit, probabil, nevoia să contracareze această alunecare către tehnicism prin alcătuirea unui manual de bune practici în arta de a predica, iar această întreprindere cărturărească s-a dovedit foarte rodnică și influentă ${ }^{4}$. De aceea, începînd cu secolul al patrulea, în ciuda cunoștințelor solide de cultură clasică, se observă la marii retori creștini o preferință declarată pentru claritate, simplitate și accesibilitate. Termenul omilie, avînd ca etimon lat. bis. homilia - provenit, la rîndu-i, din gr. homilia, 'tovărășie, conversație'-trebuie înțeles ca 'sermo familiaris in Evangelium' și pune în valoare tocmai virtuțile acestui stil eficient de a cuvînta, prin care preoții interpretează pe înțelesul credincioșilor semnificațiile fragmentelor biblice citite în timpul slujbei religioase.

Din multitudinea de observaţii, comentarii și exemple pe care Sf. Augustin le aduce în sprijinul concepției sale reținem doar trei aspecte importante pentru cercetările de stilistică: a) personalitatea retorului creștin și legăturile acestuia cu auditoriul, b) finalitățile urmărite de predicator și c) tipurile de elocuție de

\footnotetext{
${ }^{3} \mathrm{O}$ foarte bună exemplu de convertire este chiar în textul lui Augustin, în care citatul biblic se învecinează cu fragmente din marii autori ai Antichității: Platon, Hesiod, Vergiliu, Cicero, Varro ș.a.

${ }^{4}$ „De doctrina christiana a fost inclusă în programul de studii al școlilor mînăstirești, a devenit un model și un ghid, atît sub aspect didactic, cît mai ales omiletic, lucrarea avînd un mare ecou şi fiind o autoritate, în special în cursul Evului Mediu occidental, dar şi în secolele care i-au urmat." (Wald, în Augustin, 2002, p. 25).
} 
care el se poate servi pentru ca discursul să fie de impact.

\section{Personalitatea discursivă a oratorului creștin}

Dacă retorii greci și romani recomandau ca oratorul să aibă o pregătire temeinică, deprinsă prin învățare și exercițiu, în viziunea Sf. Augustin elocința predicatorului este o mărturie de credință care se dezvoltă, mai degrabă, prin observație, imitare și punere în practică decît prin angrenare într-un proces formal de însușire de cunoștințe. Oratorul creștin deprinde mult mai eficient ${ }^{5}$ arta de a predica dacă stă în preajma unui maestru sau își hrănește spiritul cu scrierile și spusele maeștrilor decît dacă se lasă antrenat într-un mecanism de asimilare de informații lipsite de resorturile vii ale omenescului aflat în slujba divinității. Așa cum copiii învață să vorbească urmărindu-i și imitîndu-i pe adulți, tot astfel cineva poate ajunge un bun orator, „fără să fi luat lecții de elocință” (Augustin, 2002, p. 279), doar dacă ascultă, citește și imită expunerile unor predicatori elocvenți și cu har. Această perspectivă asupra formării predicatorului este, fără îndoială, concordantă cu doctrina cuvîntului revelat de Dumnezeu, așa cum este ea formulată în textele evanghelice $\left(M c, 13,11 ; M t, 10,19-20^{6}\right)$ și semnalează că, pentru oratorul creștin, regulile retorice au caracter intuitiv, nu prescriptiv.

În personalitatea predicatorului, elocința și înțelepciunea se împletesc, primatul fiind acordat înțelepciunii. Grație înțelepciunii, un vorbitor lipsit de elocință se face util ascultătorilor săi, însă un vorbitor „care varsă șuvoaie de elocință nechibzuită este de evitat” (Augustin, 2002, p. 283). În viziunea Sf. Augustin, adevărata înțelepciune provine de la Dumnezeu, iar cuvîntarea predicatorului trebuie să fie expresia inspirației pe care vorbitorul o primește de la divinitate. Idealul discursiv de care retorul creștin trebuie să se lase călăuzit este textul biblic, în care există „toate calitățile și toate podoabele elocinței” (Augustin, 2002, p. 287). Ideea că naturalețea şi spontaneitea expresiei nu se supun unor norme rigide predeterminate, ci le guvernează, este solidară cu inovaţia de a considera că substanța discursului este mai importantă decît forma acestuia. Ceea ce se spune este mai relevant decît felul în care se spune. Privilegierea conținutului comunicat aduce în prim plan o constantă a predicii, și anume grija faţă de ascultător. Acesta trebuie îndrumat să înțeleagă adevărul textului revelat ${ }^{7}$ și să îl urmeze în viața de zi de cu zi. În viziunea primilor retori creștini, oratorul nu mai este un cuceritor al minților și inimilor ascultătorilor, ci un învățător care cultivă binele, se îngrijește de formarea credincioșilor și se află în slujba comunității.

Prin felul său de a fi și de a vorbi predicatorul trebuie să fie un exemplu demn de urmat și această mentalitate rezonează, de asemenea, cu preceptele retoricii greco-latine potrivit cărora autoritatea și prestigiul oratorului decurg în mod firesc din noblețea de caracter a acestuia. Nu poate ajunge orator decît omul corect, concluzionează Quintilian (1974, III, p. 333), argumentînd că ,dacă frumosul talent al oratoriei ar ajunge la dispoziția răutăţii, nimic nu ar fi mai primejdios pentru interesele publice și private decît elocința" (idem). Sprijinindu-se pe cuvintele apostolului Pavel (1Tim, 4, 12), Sf. Augustin nu vizează doar autoritatea morală a vorbitorului, ci toate aspectele vieții sale: „fă-te credincioșilor pildă în cuvînt, în purtare, în iubire, în duh, în credință, în curăție" (Anania, 2009, p. 1704). Se poate, deci, constata, că retorica creștină s-a edificat pe credința că nu atît cuvintele, cît exemplele de trăire umană care urmează modelul hristic au cea mai mare forță de convingere.

\section{Finalitățile urmărite de predicator}

Prin raportare la tripticul clasic al scopurilor urmărite de orator (docere, delectare, movere), Sf. Augustin afirmă că nici un predicator nu ar trebui să neglijeze cele trei țeluri retorice, însă reformulează finalitățile

\footnotetext{
5 „[...] dacă este abordată de un spirit pătrunzător și doritor să învețe, elocința se prinde mai ușor de cei care îi citesc și îi ascultă pe vorbitorii de frunte decît de aceia care urmează preceptele acestei arte.” (Augustin, 2002, p. 279).

${ }^{6}$ „Iar cînd vă vor da în mîna lor, nu vă îngrijorați de cum sau ce veți vorbi, că în ceasul acela vi se va da vouă ce să vorbiți;/ fiindcă nu voi sînteți cei ce vorbiți, ci Duhul Tatălui vostru este Cel ce grăiește întru voi." (Anania, 2009, p. 1471).

${ }^{7}$ „[...] cui îi folosește o exprimare corectă pe care intelectul ascultătorului nu o poate înțelege?”, se întreabă retoric Augustin (2002, p. 309).
} 
astfel încît să fie adecvate specificului doctrinar și discursiv al creștinimului. Cuvîntarea predicatorului se cuvine urmărită cu înțelegere, cu încîntare și cu înduplecare ${ }^{8}$ (Augustin, 2002, p. 313). Cele trei țeluri reflectă gradele de intensitate ale procesului persuasiv. Pentru cei ce ascultă predica, înțelegerea determină acceptare, aprobare, consimțămînt și, mai apoi, favorizează convingeri în plan mentalitar și comportamental.

Autorul lucrării De doctrina christiana dedică pagini memorabile celor trei scopuri expresiv-persuasive și impune cîteva schimbări importante.

O primă inițiativă este de a simplifica arhitectura discursului, prin restrîngerea etapelor de elaborare la invenție (ce se spune) și elocuţie (cum se spune). În retorica antică aceste operații erau considerate cele mai importante (Augustin, 2002, p. 426, nota 1), și pentru a valida teza oratorului inspirat (v. și Gafton, 1995, p. 30), Sf. Augustin le statornicește ca etape de bază în realizarea unei predici ${ }^{9}$. Invenției îi este rezervat rolul de a pregăti transmiterea adecvată a unei interpretări autorizate a textului biblic, iar elocuția trebuie să pună în valoare adevărul revelat.

Actul de a înțelege are, în elocința creștină, o dublă orientare, dinspre autoritatea textului sacru către predicator și, mai apoi, dinspre text și oratorul creștin către credincioșii cărora el li se adresează. Pe de o parte, predicatorul, ca interpret autorizat, meditează la semnificațiile textului sacru și, în acest context, e important să semnalăm că, în Evul Mediu, exegeza biblică a instituit un canon hermeneutic cu patru nivele (cf. Nate, 2006, p. 24): a) literal sau istoric (sensus literalis), b) alegoric (sensus allegoricus), c) moral sau tropologic (sensus moralis/tropologicus) și d) anagogic sau mistic/eshatologic (sensus anagogicus) ${ }^{10}$. Pe de altă parte, predicatorul are datoria de a le dezvălui credincioșilor semnificațiile secvențelor din Scriptură citite în timpul serviciului religios, astfel încît ascultătorii să adere, prin conduita lor, la învăţăturile de credință. Încîntarea și determinarea la acțiune a ascultătorilor își au izvorul în actul de a înțelege și, prin înţelegere, în propensiunea ascultătorilor de a îmbrăţișa și împărtăşi adevărul biblic.

Prin urmare, o a doua schimbare este de a separa rolul capital rezervat ințtelegerii de rolurile, derivate, ale încîntării și înduplecării. Înțelegerea este înfățișată ca necesitatea de a-i instrui pe credincioși în lumina adevărului biblic, de a-i determina să ia aminte la ceea ce se spune, în timp ce încîntarea și înduplecarea sînt finalități ce pot fi atinse doar dacă înțelegerea este asigurată cu eficiență.

Repertoriul de strategii ale delectării și mișcării ascultătorilor este alcătuit și exemplificat cu atenție. Ori de cîte ori predicatorul „vrea să îl și încînte pe acela căruia îi vorbește sau să îl înduplece, nu o va face vorbind cum îi vine, ci este important cum vorbește ca să o facă. Or, după cum este necesar ca auditoriul să fie încîntat, ca să fie ținut atent, tot aşa, este necesar să fie înduplecat, ca să fie determinat spre acțiune. Și după cum este încîntat dacă vorbești plăcut, tot aşa este înduplecat dacă este atras de ce îi promiți, dacă se teme de amenințarea pe care i-o pui în față, dacă urăște ce critici, dacă ce susții aprobă, iar ce insiști că trebuie deplîns deplînge şi el; cînd se bucură de bucuria pe care i-o predici; cînd se îndură de aceia pe care îi pui înainte ochilor spunîndu-i că sînt vrednici de milă; cînd îi evită pe aceia pe care îi prezinți speriindu-l că trebuie să fugă de ei; și orice altceva se poate face cu elocință înaltă pentru a impresiona

\footnotetext{
${ }^{8}$ Un termen mai potrivit pentru a descrie comportamentul ce trebuie indus auditoriului este cel de ascultare. În sens creștin, ascultarea este făgăduința și totodată practica de a urma în chip neabătut calea către mîntuire, de a-l urma pe Hristos.

9 „Începînd cu secolul al XIII-lea, se acumulează evidențele referitoare la diversitatea activităților de a predica. În mare, există trei feluri de predici: prezentarea simplă și limpede a învăţăturii biblice, recursul la tehnici de expunere și de divizare proprii stilului erudit de tip universitar și predica populară, cu exemple moralizatoare din pilde, snoave, legende ale sfinților și istorisiri de întîmplări miraculoase. [...]

Predica tipică are șase părți: 1. tema: un citat biblic (din liturghia zilei), urmat de o rugăciune; 2. protema, o secvență introductivă a temei (aceasta constă într-un citat dintr-un alt fragment biblic, pus în legătură cu primul); 3. antetema: introducerea propriu-zisă în temă, prin reafirmarea scopului predicii, 4. divizarea temei, în trei părți sau în multipli de cîte trei, cu citate de autoritate care să susțină fiecare diviziune - aceasta este etapa-cheie de dezvoltare exegetică și comentativă; 5 . subdivizarea temei și 6. amplificarea sau extinderea fiecărei diviziuni sau subdiviziuni.” (Copeland \& Ziolkowski, 2006, p. 494-495).

${ }^{10}$ De exemplu, în viziunea Sf. Ioan Casian, numele „Ierusalim” poartă, în textul sacru, următoarele valori: istorică („oraş”), alegorică („Biserică a lui Hristos”), morală („suflet al omului”) și anagogică („Ierusalimul-cel-de-sus, mamă a tuturor”, cf. Gal, $4,26)$.
} 
sufletul auditoriului, nu ca să știe ce este de făcut, ci ca să facă ceea ce știu deja că este necesar să facă.” (Augustin, 2002, p. 313, 315).

Dacă admitem că, în concepția Sf. Augustin, funcția informativă a discursului potențează o funcție de tip formativ, putem considera că rolul de a instrui este de ordin obiectiv, adică referitor la ceea ce se spune, iar rolurile derivate, încîntarea și înduplecarea, sînt de ordin (inter)subiectiv, adică reliefează personalităţile protagoniştilor comunicării (orator şi ascultători) și relațiile dintre ei. Distincția este pertinentă și foarte utilă în a sublinia că farmecul și puterea de convingere a elocinței decurg din capacitatea limbajului uman de a exprima ceea ce ființa umană percepe ca fiind esențial și adevărat.

$\mathrm{O}$ a treia modificare promovată în De doctrina christiana este de a asocia energiile care animă procesul de persuasiune, respectiv logosul, ethosul și pathosul, cu triada scopurilor urmărite de predicator, ințtelegerea, incîntarea și înduplecarea, iar această împrospătare a tiparelor clasice se observă mai ales în reconfigurarea sistemului celor trei stiluri.

\section{Tipurile de elocuție}

În descrierea retorică antică, compunerea și rostirea discursului sînt guvernate de regulile genului retoric adoptat și potrivite cu situația de comunicare, atît cea reală cît și cea reprezentată discursiv. De la caz la caz, oratorul poate recurge la tipuri distincte de elocuție (stil). Stilul simplu se folosește cu rol informativ, dezideratele recursului la stilul temperat sînt armonia, eleganța și măsura, iar stilul înalt are o bogată împodobire expresivă.

Sf. Augustin adaptează modelele tradiţionale la lumea nouă a realităţilor discursive ale creștinismului. În viziunea sa, predicatorul adoptă stilul simplu atunci cînd oferă învăţături, pe cel temperat cînd face aprecieri și stilul înalt, cînd auditoriul trebuie îndemnat cu insistență să trăiască în acord cu litera și spiritul textului sacru, să treacă de la înțelegere la acțiune, să sublimeze cuvîntul de învăţătură în comportament. În oratoria creștină, esența stilului simplu constă în profunzimea raționamentelor ${ }^{11}$, dominanta sa fiind logosul, stilul temperat este caracterizat de echilibrul reliefării ${ }^{12}$, dominanta sa fiind ethosul, iar principala proprietate a stilul înalt este vitalitatea ${ }^{13}$, dominanta sa fiind pathosul. Altfel spus, stilul simplu acționează „asupra minții sau a rațiunii, nu a sentimentelor sau a voinței, el vizează o modificare a raționamentului”, stilul temperat „poate, prin aptitudinea sa de laudă sau blam, să influențeze pe auditor și să-l determine săși schimbe modul de viață, dar nu direct și nici în mod obligatoriu”, iar stilul înalt ,atinge sufletul și poate provoca, în ultimă instanță, chiar o schimbare a modului de viață” (Wald, în Augustin, 2002, p. 441).

Prin raportare la canoanele antice, luminatul învăţat formulează două principii care dirijează eficacitatea persuasivă și expresivă a actului de a predica. Primul dintre acestea este principiul adecvării stilistice. Pentru a dobîndi eficiență maximă, predicatorul este liber să fructifice în acelaşi discurs toate cele trei tipuri de elocuție ${ }^{14}$. Utilizarea variată și armonioasă a valențelor celor trei stiluri este consemnată de la Aristotel la Quintilian. Acesta din urmă afirmă că echilibrul conjuncției între tipurile de elocuție asigură succesul deplin al cuvîntării: „Deci totul în discurs să fie mare, nu exagerat; sublim, nu abrupt; curajos, nu temerar; sever, dar nu trist; grav, dar nu greoi; vesel, nu luxuriant; plăcut, nu neînfrînat; grandios, nu emfatic. La

${ }^{11}$ „T,ine deci de obligația învățătorului nu doar să deschidă ceea ce este închis și să desfacă nodurile întrebărilor, ci și, în timp ce se face acest lucru să preîntîmpine alte întrebări care pot apărea” (Augustin, 2002, p. 335).

${ }^{12}$ În oratoria ecleziastică, ornamentele stilului temperat trebuie exploatate „nu cu emfază, ci cu măsură” (Augustin, 2002 , p. 365).

${ }^{13}$ Stilul înalt „se deosebește de stilul temperat, mai ales prin aceea că nu este atît împodobit cu ornamente verbale, cît impetuos prin trăirile interioare; căci de primit primește, desigur, acele ornamente, aproape toate, dar, dacă nu le are, nu le caută. De fapt, este purtat de propriul elan, iar frumusețea enunțului, dacă apare, o ia din forța subiectului, nu din grija pentru ornament; îi este deajuns, desigur ca, în vederea acestui scop, cuvintele potrivite să fie nu alese prin truda buzelor, ci să urmeze înflăcărarea inimii” (Augustin, 2002, p. 339).

${ }^{14}$ „Și să nu se creadă că amestecul acestor trei stiluri ar fi contrar teoriei; dimpotrivă, trebuie ca, pe cît se pretează mai bine subiectul, enunțul să fie variat prin utilizarea tuturor celor trei stiluri, deoarece întrebuințarea excesivă a unuia singur face să scadă atenția auditoriului. Cînd se trece însă de la un stil la altul, discursul progresează mai armonios, chiar dacă devine mai lung" (Augustin, 2002, p. 357) 
fel, pentru tot restul. Și, în general, calea cea mai sigură este calea de mijloc, fiindcă în extreme constă greșeala" (Quintilian, 1974, III, p. 408).

Sf. Augustin rafinează acest construct teoretic arătînd că cele trei finalități discursive: a îțtelege, a incînta și $a$ indupleca se manifestă unitar în discurs. Conform acestui principiu pe care l-am putea numi al unității persuasive, a înțelege, a plăcea și a se supune se potențează reciproc: „cine nu știe că, dacă nu este înțeles, oratorul nu poate fi ascultat nici cu plăcere, nici cu supunere?”, se întreabă, retoric, Augustin (2002, p. 365), inainte de a avansa ideea că scopurile urmărite de predicator se organizează, de la un caz la altul, în jurul unei finalități dominante, celelalte două fiind subsumate centrului persuasiv. Astfel, deși stilul simplu are ca finalitate principală limpezimea raționamentelor (înțelegerea), încîntarea și supunerea nu sînt excluse ca finalități de grad secund. În stilul temperat, întîietatea o deține încîntarea, însă înțelegerea și supunerea se pot și ele actualiza. În sfîrșit, în stilul înalt, înduplecarea unei inimi de piatră nu este posibilă dacă ceea ce se spune „nu este ascultat și cu înțelegere și cu încîntare” (Augustin, 2002, p. 367).

$\mathrm{Nu}$ doar aspectele teoretice demonstrează că Sf. Augustin a avut o contribuție crucială la fondarea retoricii creștine, ci şi analizele pe care autorul le propune pentru a dovedi că Scriptura este prototip de elocvență. Dacă ținem cont de abundența de ilustrări, nu este greșit să considerăm că De doctrina christiana este un ghid foarte valoros de hermeneutică biblică și de retorică creștină. Sf. Augustin este întîiul mare gînditor creștin „care discută pe larg despre utilitatea retoricii în misiunea creștină de interpretare și răspîndire a cuvîntului lui Dumnezeu" (Habinek, 2005, p. 89). Spre deosebire de gînditorii și retorii precreștini, în ale căror concepții retorica era meșteșugul comunicativ de a interpreta în mod convingător o anumită realitate, pentru predicatorii creștini, și Sf. Augustin insistă asupra acestui fapt, ars bene dicendi este aservită comunicării adevărului revelat prin textul sacru. În concepția sa, „descoperirea sau invenția nu mai constă în căutarea celor mai bune argumente sau mijloace persuasive, ci în dezvăluirea adevărului biblic. Celelalte etape retorice (stilul, memoria, pronunțarea) sînt și ele considerate mijloace prin care respectivul adevăr este comunicat unui anumit auditoriu. De fapt, autorii creștini sînt, mai mult decît predecesorii lor păgîni, cei ce impun viziunea conform căreia stilul este modalitatea electivă de a transmite un conținut prealabil, aflat mereu la dispoziție” (idem).

\section{Concluzii}

Patrimoniul retoric al creștinismului îmbogățește moștenirea retorică a Antichității, prin impunerea unei perspective noi, a cărei importanță nu poate fi neglijată pe terenul cercetărilor de retorică și stilistică:

a) prin adoptarea şi adaptarea preceptelor retorice antice, fondatorii hermeneuticii și retoricii creștine dezvoltă o tradiție normativă care a conferit artei oratorice și analizei textuale imbolduri noi (Murphy, 2001, p. 61);

b) în viziunea fondatorilor retoricii creștine, țelul suprem al artei de a predica nu este cel de a mișca mințile şi inimile auditoriului, așa cum recomandau învățații antici, ci de a călăuzi ființa umană către adevărul revelat de textul sacru;

c) pentru apologeții creștini, idealul de elocință trebuie căutat în litera și spiritul textului biblic;

d) oratorul creștin trebuie să fie un exemplu viu, care convinge mai mult prin felul său de a fi în lume și mai puţin prin meșteșugul de a compune cuvîntări frumos ornate și bine argumentate;

e) eficacitatea discursivă a predicatorului se întemeiază pe adecvarea resurselor de limbaj la solicitările expresive și persuasive ale situației de comunicare și pe unitatea ierarhic actualizată a scopurilor urmărite de orator.

\section{Bibliografie}

Anania 2009 = Biblia sau Sfânta Scriptură, versiune diortosită după Septuaginta, redactată, adnotată și tipărită de Bartolomeu Valeriu Anania, Arhiepiscop al Vadului, Feleacului şi Clujului, Mitropolit al Clujului, Albei, Crişanei şi Maramureșului, Editura Renașterea, Cluj-Napoca, 2009. 
Augustin 2002 = Sfîntul Augustin, De doctrina christiana: introducere în exegeza biblică, traducere de Marius Ciucă, introducere, note și bibliografie de Lucia Wald, Editura Humanitas, București, 2002.

Clarke, M. L. (1996). Rhetoric at Rome: a Historical Survey, third edition, revised and with a new introduction by D. H. Berry, Routledge, London, New York, Crossref.

Copeland, R. \& Ziolkowski, J. (2006). Medieval rhetoric, în Sloane, Thomas O., (coord.), Encyclopedia of Rhetoric, Oxford University Press, p. 487-497, Crossref.

Dowden, K. (2007). Rhetoric and Religion, în Worthington, Ian (ed.), A Companion to Greek Rhetoric, Blackwell Publishing, p. 320-333.

Gafton, Al. (1995). O ipoteză interpretativă asupra sintagmei paulinice „a vorbi în limbi”, în „Echidistanțe”, nr. 7-8, p. 29-31.

Habinek, Th. (2005). Ancient Rhetoric and Oratory, Blackwell Publishing, Crossref.

Knape, J. (2008). Rhetorik und Stilistik des Mittelalters, în Fix, U., Gardt, A. \& Knape, J. (Hrsg.), Rhetorik und Stilistik. Ein Internationales Handbuch historischer und systematischer Forschung/ Rhetoric and Stylistics. An International Handbook of Historical and Systematic Research, vol. I, Walter de Gruyter, Berlin, New York, p. 55-72.

Kneidel, G. (2006). Homiletics, în Sloane, Thomas O., (coord.), Encyclopedia of Rhetoric, Oxford University Press, p. 362-366, Crossref.

Murphy, J.J. (2001). Rhetoric in the Middle Ages. A History of Rhetorical Theory from Saint Augustine to the Rennaissance, Arizona Center for Medieval and Renaissance Studies.

Nate, R. (2006). Allegory, în Sloane, Thomas O., (coord.), Encyclopedia of Rhetoric, Oxford University Press, p. 23-26, Crossref.

Quintilian (1974). Arta oratorică, ediție în limba română de Maria Hetco, 3 vol., Editura Minerva, București. 